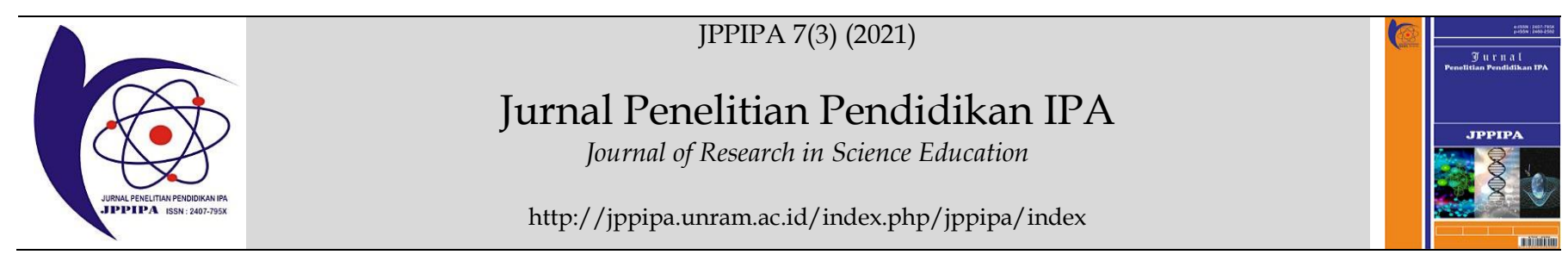

\title{
The Use of Tungsten in Potentiometry to Detect Pospat Baffer and Urease Enzyme
}

\author{
Victor H. Sihombing ${ }^{1}$, Abd Hakim S1* \\ ${ }^{1}$ Department of Physics, Faculty of Mathematics and Natural Sciences, Medan State University, Indonesia.
}

DOI: $10.29303 /$ jppipa.v7i3.699

\section{Article Info}

Received: March 15th, 2021

Revised: May 20th, 2021

Accepted: May 26th 2021

\begin{abstract}
This study aims to characterize phosphate buffer and urease enzymes through the absorbance spectrum of UV-Vis and FTIR using tungsten as the indicator electrode. The method used in this research is the biosensor potentiometric method carried out in the Laboratory of the Faculty of Mathematics and Natural Sciences, State University of Medan and the Beacukai Belawan Medan laboratory. The absorbance characterization of electrolyte solutions in various compositions using UV-Vis showed that phosphate buffer solution $0.001 \mathrm{M} \mathrm{pH} 7.5+\mathrm{KCl} 0.001 \mathrm{M}+$ urea $0.001 \mathrm{M}+3$ drops urease enzyme had the highest absorbance compared to electrolyte solutions with phosphate buffer and urea content. Likewise, the FTIR results showed the same thing where phosphate buffer

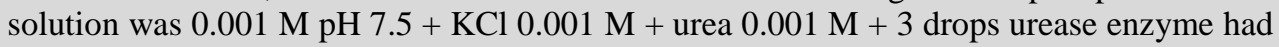
the highest\% $\mathrm{T}$ (transmission) pattern of phosphate buffer solution and urea. The urease enzyme in this study functions as a catalyst. Based on UV-Vis and FTIR characterization, it was concluded that the phosphate buffer solution of $0.001 \mathrm{M} \mathrm{pH} 7.5+\mathrm{KCl} 0.001 \mathrm{M}+$ urea $0.001 \mathrm{M}+3$ drops of urease enzyme was the best.
\end{abstract}

Keywords: Electrolyte Solution; Tungsten UV-Vis; FTIR; Biosensor Potentiometry

Citation: Sihombing, V., \& Hakim, S.A. (2021). The Use of Tungsten in Potentiometry to Detect Pospat Baffer and Urease Enzyme. Jurnal Penelitian Pendidikan IPA, 7(3), 325-330. doi:https://doi.org/10.29303/jppipa.v7i3.699

\section{Introduction}

A potentiometric sensor is a device that measures the voltage between two indicator electrodes and a reference electrode depending on the concentration of the analyte, without contradicting the electrochemical cell (Khopkar, 1990; Skoog, 2007; Wang et al., 2008).

The analyte binds the bioreceptors to the surface of the indicator electrode in a buffer solution, resulting in a potential difference between the two electrodes. Potentiometric sensors provide attractive and achievable opportunities to carry out biomedical, environmental, and industrial analyzes from a centralized laboratory, because these sensors are generally easy to use, portable, simple, and inexpensive (Gurtova et al., 2013).
The amount of electric potential in the potentiometric cell depends on the electrolyte solution and to obtain the maximum electric potential, the electrolyte solution is optimized. Potentiometric cells require an electrolyte solution consisting of a buffer as a voltage stabilizer, the urease enzyme functions as a catalyst (accelerator of the enzymatic reaction process), $\mathrm{KCl}$ to see the activity and sensitivity of the solution and urea as an analyte with a certain composition in order to obtain optimum results (Gosser, 1993; Hakim, 2018).

The method used in this research is biosensor potentiometry because potentiometric cells use enzymes. Potentiometric cell ISE (Ion Selective Electrode) electrolyte solution consisting of phosphate buffer, $\mathrm{KCl}$, urease and urea enzymes. The electrolyte 
solution varied with $\mathrm{pH}$ and molarity concentrations. Optimization procedures used in this study were (1) phosphate buffer optimized molarity and $\mathrm{pH}$ to determine the acid-base properties of phosphate buffer, (2) phosphate buffer plus $\mathrm{KCl}$ and urea were optimized molarity and $\mathrm{pH}$ to determine urea sensitivity and (3) phosphate buffer plus $\mathrm{KCl}$, the urease and urea enzymes were optimized for molarity and $\mathrm{pH}$ to determine the performance of the urease enzyme catalyst and the response time to the electrolyte solution voltage signal.

Optimization of each phosphate buffer, $\mathrm{KCl}$, urea with enzymes has been carried out. Phosphate buffer $0.001 \mathrm{M}$ pH 7.5, KCl $0.001 \mathrm{M}$, urea $0.001 \mathrm{M}$ (S., A. H 2018). The procedure used was phosphate buffer mixed with $\mathrm{KCl}$ and injection urease enzyme with urea $10 \mu \mathrm{L}$ but the results were not optimal. To save costs and time to characterize electrolyte solutions, electrochemical processes are not carried out, only to characterize electrolyte solutions using FT-IR and UV-Vis from variations in molarity and $\mathrm{pH}$. Next, the time response is carried out so that the potentiometric cell acts as a voltage meter in the time interval using a potentiometer and a lab power through a computer display.

UV-VIS spectrophotometer is a type of equipment used to measure the absorption of organic or inorganic molecules given a light source with a wavelength range in the UV-VIS region (180-770 nm). The advantages of this method include producing a greater maximum absorbance and faster analysis (Hikmatullah, 2013; Mulja \& Suharman, 1995).

FT-IR is Fourier Transform InfraRed spectrophotometry is very important in modern chemistry, especially in the field of organic chemistry as a routine tool in functional group discovery, compound recognition, and mixture analysis (Khan et al., 2002; Goodier, 2006).

Potentiometric enzyme biosensors are easy detectors for quantification of urea concentration in industrial processes, or for monitoring patients with diabetes, kidney damage or liver damage (Lai et al, 2017). Measurement of urea concentration in blood shows indications of kidney and liver function, liver/heart failure, excessive protein or protein catabolism input, malnutrition, pregnancy, shock and pressure (Davey, 2005; Hakim et al., 2019).

Based on the above conditions, research was carried out, which first characterized the electrolyte solution using FT-IR, UV-Vis then carried out optimization of the phosphate buffer electrolyte solution plus urea and phosphate buffer plus $\mathrm{KCl}$, the urease enzyme was injected with urea and carried out the response time of the electrolyte solution using Potensoimetric cells use tungsten as the indicator electrode.

\section{Method}

The materials used urea standard 56180 SigmaAldrich, $\mathrm{KCl}$, baffer pospat $\mathrm{KH} 2 \mathrm{PO} 4$, Enzyme EC 3.5.1.5 (Urease) U4002. Potentialometric testing was conducted using tungsten indicator electrodes (W) and RE-5B Ag/ AgCl MF-2052 reference electrodes.

Potentiometric cells consist of a reference electrode $(\mathrm{Ag} / \mathrm{AgCl})$ and an indicator electrode (selective ion (ISE)). The indicator electrode and reference electrode are immersed in a measuring cup which already contains an electrolyte solution. Potentiometric cells were filled with phosphate buffer solution and urease enzyme and stirred until homogeneous (Wang, Xu, Zhang, Li 2008). The measuring cup is placed on top of the magnetic stirrer which is used to stir and heat the electrolyte solution when mixed. Electrolyte indicators and references that function as electrochemical sensors. The potential voltage generated by the electrodes is converted by a potentiometer to $\mathrm{mV}$ and the recorded voltage signal is displayed on the computer.

The test solution consisted of phosphate and phosphate buffers plus $\mathrm{KCl}$, urease and urea enzymes. The electrolyte solution was characterized using UV Vis to see the absorbance and FTIR to see the functional groups. Then the electrolyte solution is optimized through the following steps phosphate buffer is optimized molarity and $\mathrm{pH}$ to determine its acid-base properties, phosphate buffer and phosphate buffer plus $\mathrm{KCl}$, urease and urea enzymes are optimized for molarity and $\mathrm{pH}$ to determine the performance of urease enzyme catalyst and solution voltage signal time response electrolyte.

\section{Result and Discussion}

\section{Characterization of UV-Vis}

In Figure 1 (a) it can be seen that an absorbance peak has not been formed at a wavelength of $200-300$ $\mathrm{nm}$, (b) an absorbance peak is formed at a wavelength of $240 \mathrm{~nm}$ with an absorbance peak height of 5.6939 and (c) an absorbance peak is formed at a wavelength of $257 \mathrm{~nm}$ with peak height absorbance of 9.7281 with tracking at a wavelength between $200-400 \mathrm{~nm}$.

In Figure 2 you can see three electrolyte solutions with the same phosphate buffer $\mathrm{pH}$, namely pH 5.5 which consists of (a) phosphate buffer $0.001 \mathrm{M}$ pH 5.5 + urea $0.001 \mathrm{M}$, (b) phosphate buffer $0.001 \mathrm{M}$ pH $5.5+\mathrm{KCl} 0.001 \mathrm{M}+$ urea $0.001 \mathrm{M}$ and (c) phosphate buffer $0.001 \mathrm{M} \mathrm{pH} 5.5+\mathrm{KCl} 0.001 \mathrm{M}+$ urea $0.001 \mathrm{M}+3$ drops of urease enzyme, showing the highest absorbance found in solution (c) of 5.6939 at a wavelength of $257 \mathrm{~nm}$. 
In Figure 3, it can be seen that the electrolyte solution uses the same material but different concentrations and molarities. Based on this figure, the best electrolyte solution was selected (phosphate buffer $0.001 \mathrm{M} \mathrm{pH} 7.5+\mathrm{KCl} 0.001 \mathrm{M}+$ urea $0.001 \mathrm{M}+$ urease enzyme 3 drops) with an absorbance of 9.7281 at a wavelength of $257 \mathrm{~nm}$.

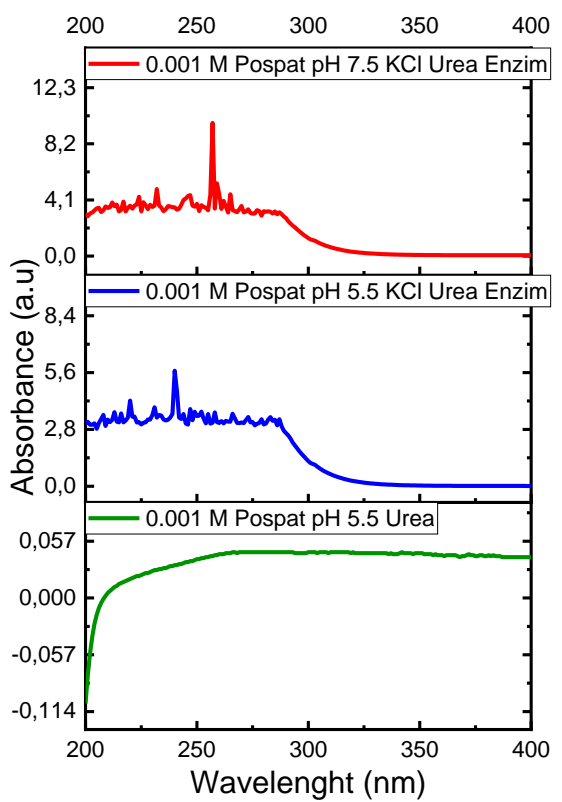

Figure 1. UV-Vis Absorbance Pattern Using Solution (a),(b) Enzyme 3 drops, (c) Urease Enzyme 3 drops

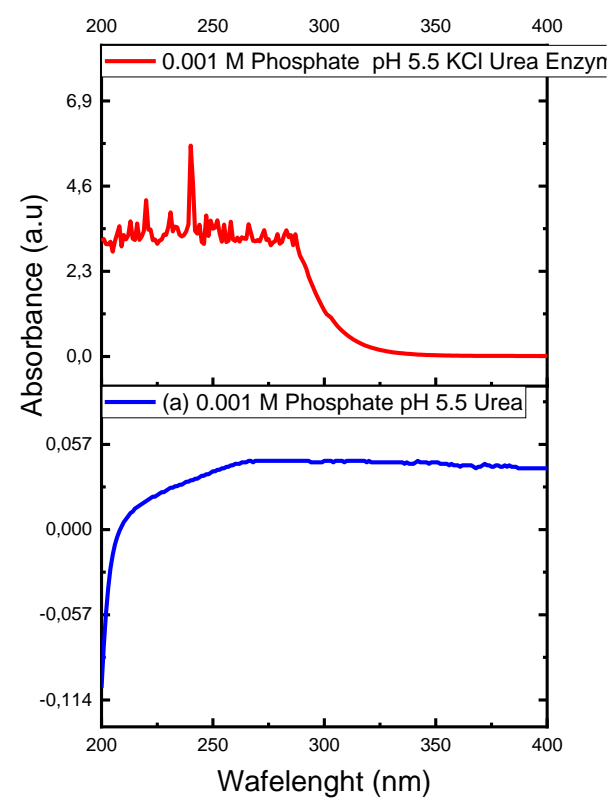

Figure 2. UV-Vis Absorbance Pattern Using Solution (a), (b) Urease Enzyme 3 drops

From the figure, it shows that the addition of a substance and concentration will change the wavelength of the absorbance peak, where the greater the concentration, the higher the absorbance peak (Misnawati 2017).

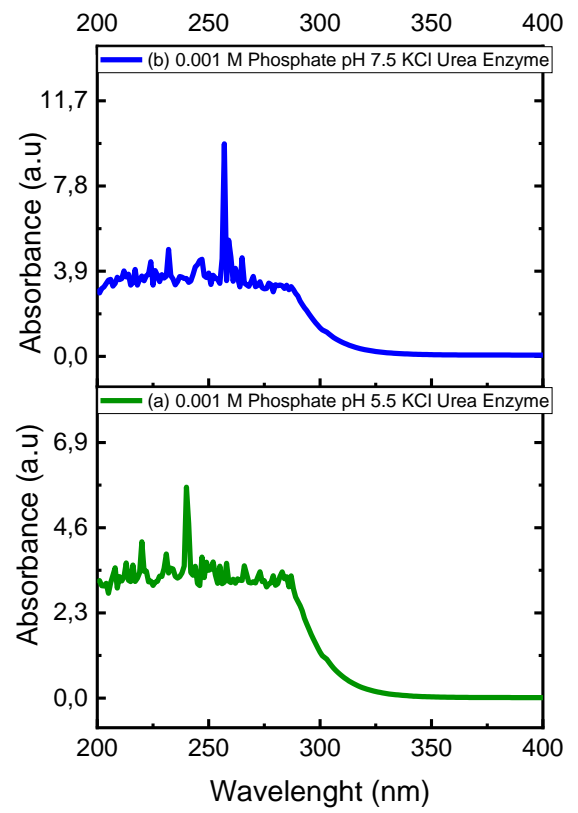

Figure 3. UV-Vis Absorbance Pattern Using Solution (a) Urease Enzyme 3 Drops and (b) Urease enzyme 3 drops

\section{Characterization of FTIR Spectrophotometer}

In Figure 4, it can be seen that the first absorption area of the solution (a) phosphate buffer $0.001 \mathrm{M} \mathrm{pH} 5.5$ $+0.001 \mathrm{M}$ urea is at wave number 3435.26 with a transmission of 0.64 and these results indicate the presence of $\mathrm{N}-\mathrm{H}$ groups. The second absorption area is at wave number 2065.74 with a transmission of 82.31 and these results indicate the presence of an $\mathrm{O}-\mathrm{H}$ group. The third absorption area is in wave number 1634.04 with a transmission of 17.31 and these results indicate the presence of the $\mathrm{C}=\mathrm{O}$ group.

In the first absorption area of the solution (b) phosphate buffer $0.001 \mathrm{M} \mathrm{pH} 5.5+\mathrm{KCl} 0.001 \mathrm{M}+$ urea $0.001 \mathrm{M}+3$ drops urease enzyme is at wave number 3435.27 with a transmission of 2.63 and these results indicate the presence of $\mathrm{N}-\mathrm{H}$ groups at wave number 2066.65 with a transmission of 86.47 and these results indicate the presence of the $\mathrm{O}-\mathrm{H}$ group. The third absorption area is at wave number 1633.66 with a transmission of 23.94 and these results indicate the presence of a $\mathrm{C}=\mathrm{O}$ group.

In the first absorption area of the solution (c) phosphate buffer $0.001 \mathrm{M} \mathrm{pH} 7.5+\mathrm{KCl} 0.001 \mathrm{M}+$ urea $0.001 \mathrm{M}+3$ drops urease enzyme is at wave number 3434.90 with a transmission of 6.56 and these results indicate the presence of $\mathrm{N}-\mathrm{H}$ groups at wave number 2064.35 with a transmission of 92.43 and these results indicate the presence of the $\mathrm{O}-\mathrm{H}$ group. The third absorption area is in wave number 1637.11 with a 
transmission of 40.99 and these results indicate the presence of the $\mathrm{C}=\mathrm{O}$ group.

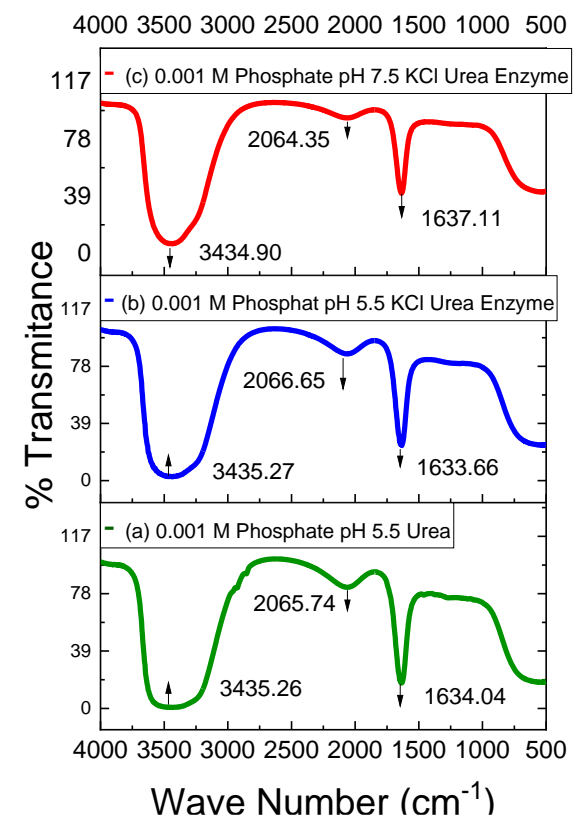

Figure 4. FTIR Transmission Pattern Using Solution (a), (b) Urease Enzyme 3 Drops, (c) Urease Enzyme 3 drops

Table 1. Results of FTIR Characterization of Electrolyte Solutions

\begin{tabular}{llll}
\hline $\begin{array}{l}\text { Electrolyte } \\
\text { Solution }\end{array}$ & $\begin{array}{l}\text { Wave } \\
\text { Number } \mathrm{cm}^{-1}\end{array}$ & $\begin{array}{l}\text { \%Transmi- } \\
\text { ssion }\end{array}$ & $\begin{array}{l}\text { Functional } \\
\text { Group }\end{array}$ \\
\hline Phosphate & 3435.26 & 0.64 & $\mathrm{~N}-\mathrm{H}$ \\
Buffer & 2065.74 & 82.31 & $\mathrm{O}-\mathrm{H}$ \\
pH 5.5 & 1634.04 & 17.31 & $\mathrm{C}=\mathrm{O}$ \\
+ Urea & & & \\
Phosphate & 3435.27 & 2.63 & $\mathrm{~N}-\mathrm{H}$ \\
Buffer & 2066.65 & 86.47 & $\mathrm{O}-\mathrm{H}$ \\
pH 5.5 +KCl & 1633.66 & 23.94 & $\mathrm{C}=\mathrm{O}$ \\
+ Urea + & & & \\
Urease & & & \\
Enzyme & & & $\mathrm{N}-\mathrm{H}$ \\
Phosphate & 3434.90 & 6.56 & $\mathrm{O}-\mathrm{H}$ \\
Buffer pH & 2064.35 & 92.43 & $\mathrm{C}=\mathrm{O}$ \\
7.5 $+\mathrm{KCl}+$ & 1633.66 & 40.99 & \\
Urea + & & & \\
Urease & & & \\
Enzyme & & & \\
\hline
\end{tabular}

Table 1 shows the results of the wave numbers read from the four wavelength graphs. In Figure 5 it can be seen that the transmission area of the two electrolyte solutions that are absorbed is the area of wave numbers 3400, 2000 and $1600 \mathrm{~cm}-1$, where the peak area shows the presence of $\mathrm{N}-\mathrm{H}, \mathrm{O}-\mathrm{H}, \mathrm{C}-\mathrm{O}$ bonds. The solution shows the highest transmission in solution (b) of 103.63. The addition of $\mathrm{KCl}$ and the urease enzyme causes a decrease in absorption, the IR absorption shifts and the formation of new absorption in a certain wave number area. Changes in spectrum patterns that occur due to the process of activation or addition of substances (Lempang, et al., 2011).

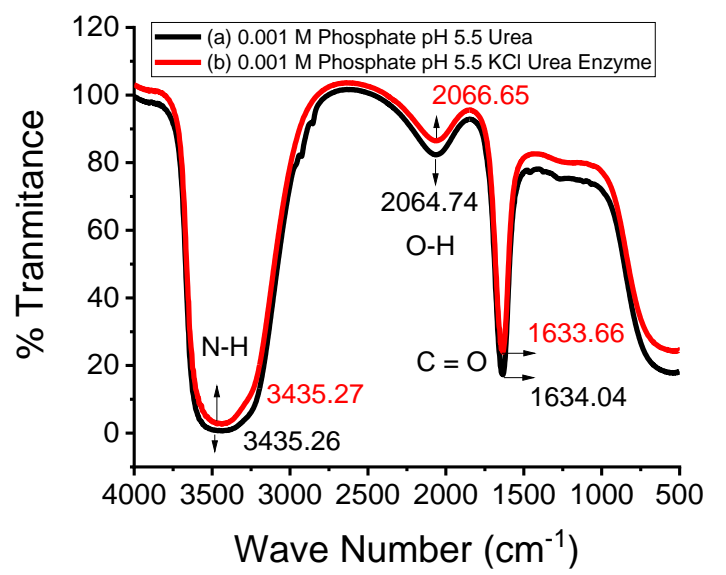

Figure 5. FTIR Transmission Pattern Using Solution (a), (b) Urease Enzyme 3 drops.

Solution (b) has an increase in absorption when compared to (a), a shift in the wave number and $\% \mathrm{~T}$ in the $\mathrm{OH}$ functional group after being activated with the urase enzyme, which functions as a catalyst. The protonated state shows that the $\mathrm{O}-\mathrm{H}$ bond has increased its bond character and its length has increased so that there is a decrease in vibration (Sastrohamidjojo, 1991). This decrease in vibration causes a shift in the wave number and an increase in $\%$ $\mathrm{T}$ (b) after being activated with 3 drops of urease enzyme.

Figure 6 shows that there is an enlargement or increase of the transmission pattern that occurs in the phosphate buffer $0.001 \mathrm{M} \mathrm{pH} \mathrm{7.5+KCl} 0.001 \mathrm{M}+0.001$ $\mathrm{M}$ urea +3 drops of urease enzyme. While phosphate buffer $0.001 \mathrm{M} \mathrm{pH} 5.5+\mathrm{KCl} 0.001 \mathrm{M}+$ urea $0.001 \mathrm{M}+3$ drops of urease enzyme reduce the transmission pattern. The FTIR spectrum pattern of transmission (b) which has a higher $\mathrm{pH}$ in Figure 6 indicates that the resulting transmission tends to be more polar (Wibowo et al. 2011).

From the results of the UV-Vis test, it was concluded that the addition of the concentration will increase the absorbance of the electrolyte solution. And the UV-Vis absorption pattern of the phosphate buffer solution with $\mathrm{KCl}$, urea and urease enzymes was more prominent than the electrolyte solution with phosphate buffer and urea content as in Figure 2 as well as the FTIR results showing the same thing where the phosphate buffer solution with $\mathrm{KCl}$ and urea has increased transmission from phosphate buffer solution and urea as shown in Figure 5, while the phosphate buffer solution with $\mathrm{KCl}$, urea and urease enzymes again triggers the transmission of phosphate buffer solution 
and urea, so the urease enzyme follows its function as a catalyst.

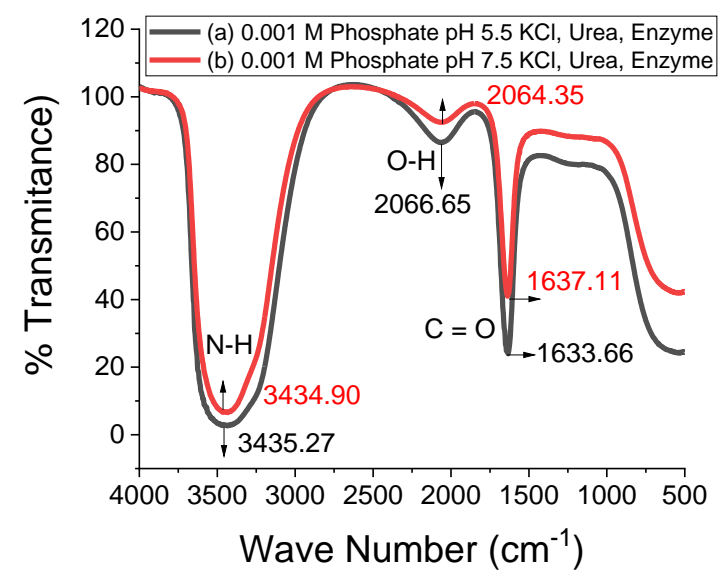

Figure 6. FTIR Transmission Pattern Using Solution (a)

Urease Enzyme 3 Drops and (b) Enzymes Urease 3 drops

It should be noted that the addition of each substance in a solution acts as an increase in transmission and catalyst through FTIR. It is necessary to synchronize the absorbance pattern with the transmission pattern of an electrolyte solution.

\section{Conclusion}

The variations in the composition of the electrolyte solution used in $\mathrm{pH}$ and molarity are as follows (1) first solution: phosphate buffer $0.001 \mathrm{M} \mathrm{pH}$ $5.5+$ urea $0.001 \mathrm{M},(2)$ third solution: phosphate buffer $0.001 \mathrm{M} \mathrm{pH} 5.5+\mathrm{KCl} 0.001 \mathrm{M}+$ urea $0.001 \mathrm{M}+$ urease enzyme 3 drops, (3) fourth solution: phosphate buffer $0.001 \mathrm{M} \mathrm{pH} \mathrm{7.5} \mathrm{+} \mathrm{KCl} 0.001 \mathrm{M}+$ urea $0.001 \mathrm{M}+$ urease enzyme 3 drops. The absorbance characterization of electrolyte solutions in various compositions using UVVis showed that phosphate buffer solution $0.001 \mathrm{M} \mathrm{pH}$ $7.5+\mathrm{KCl} 0.001 \mathrm{M}+$ urea $0.001 \mathrm{M}+$ urease enzyme 3 drops had the best absorbance. Characterization of functional groups of electrolyte solutions in various compositions using FTIR showed that phosphate buffer $0.001 \mathrm{M} \mathrm{pH} 7.5+\mathrm{KCl} 0.001 \mathrm{M}+$ urea $0.001 \mathrm{M}+3$ drops urease enzyme had the best $\% \mathrm{~T}$ (transmission).

\section{References}

Davey, P. (2005). At a Glance Medicine. Jakarta. Erlangga.

Goodier, J. (2006). Forensic Science: An Encyclopedia of History, Methods and Techniques. Reference Reviews, 20(6), 43-44. doi: https://doi.org/10.1108/09504120610687344
Gosser, D.K. (1993). Cyclic Voltammetry Simulation and Analysis of Reaction Mechanism. USA. VCH Publisher

Gurtova, O., Ye, L., \& Chmilenko, F. (2013). Potentiometric propranolol-selective sensor based on molecularly imprinted polymer. Analytical and bioanalytical chemistry, 405(1), 287295. https://doi.org/10.1007/s00216-012-6493-6

Hakim, S.A, Tarigan, K., Situmorang, M., \& Sembiring, T. (2019). Characterization Membrane Composition Of PVA-Enzyme Coating PVCKTpCIPB As Urea Sensor With UV-VIS, SEMEDX and XRD. Journal of Physics: Conference Series, 1317, 12042. doi: https://doi.org/10.1088/17426596/1317/1/012042

Hakim, S.A. (2018). Karakterisasi Urea Dalam Larutan Buffer Menggunakan Enzim Urease Dengan Metode Potensiometri. Prosiding Seminar Nasional SINASTEKMAPAN (E-Journal), I (November 2018) Universitas Quality. [Indonesian]

Khan, T. A., Peh, K. K., \& Ch'ng, H. S. (2002). Reporting degree of deacetylation values of chitosan: the influence of analytical methods. Journal of pharmacy \& pharmaceutical sciences : a publication of the Canadian Society for Pharmaceutical Sciences, Societe canadienne des sciences pharmaceutiques, 5(3), 205-212.

Khopkar, S.M. (1990). Konsep Dasar Kimia Analitik. Universitas Indonesia. Jakarta. [Indonesian]

Lai, C. K., Foot, P. J., Brown, J. W., \& Spearman, P. (2017). A Urea Potentiometric Biosensor Based on a Thiophene Copolymer. Biosensors, 7(1), 13. https://doi.org/10.3390/bios7010013

Lempang, M., Wasrin, S. \& Gustan, P. (2011). Struktur Dan Komponen Arang Serta Arang Aktif Tempurung Kemiri. Jurnal Penelitian Hasil Hutan. 29(3). 278294.

doi: https://doi.org/10.20886/jphh.2011.29.3.278-294 [Indonesian]

Misnawati, L. (2017). Karakterisasi Sampel Hasil Preparasi Dan Sintesis Graphene Oxide Berbahan Dasar Minyak Jelantah Menggunakan Metode Liquid Mechanical Exfoliation Dalam Pelarut N-Heksana Dengan Variasi Waktu Blender Dan Konsentrasi Larutan Sebagai Upaya Pemanfaatan Limbah Minyak Goreng. Yogyakarta. Universitas Negeri Yogyakarta. Jurnal Skripsi. [Indonesian]

Mulja, M., \& Suharman. (1995). Analisis Instrumental, Surabaya. Airlangga University Press. [Indonesian]

Sastrohamidjojo, H. (1991). Spektroskopi. Yogyakarta. Liberty Yogyakarta. [Indonesian]

Skoog, D.A. (2007). Principles of Instrumental Analysis. CBS College Publishing. USA 
Wang, Y., Xu, H., Zhang, J., \& Li, G. (2008). Electrochemical Sensors for Clinic Analysis. Sensors (Basel, Switzerland), 8(4), 2043-2081. doi: https://doi.org/10.3390/s8042043

Wibowo, S., Wasrin, S. \& Gustan, P. (2011). Aplikasi Arang Tempurung Kelapa sebagai Adsorben Udara Pembakaran untuk Meningkatkan Prestasi Sepeda Motor Bensin 4-Langkah. Lampung. Universitas Lampung. [Indonesian]

Winata, I. (2013). Karakterisasi Jamu Oplosan Dengan Menggunakan Alat Spektrofotometer Fourier Transform - Infra Red (FT-IR) Di Balai Pengujian Dan Identifikasi Barang. Medan. Universitas Sumatera Utara. Retrieved from: http://repositori.usu.ac.id/handle/123456789/1 8099. [Indonesian] 